\title{
PANEL BUILDING REFURBISHMENT ELEMENTS EFFECTIVE SELECTION BY APPLYING MULTIPLE-CRITERIA METHODS
}

\author{
Modestas KRACKA ${ }^{1 凶}$ and Edmundas Kazimieras ZAVADSKAS ${ }^{2}$ \\ ${ }^{1}$ Department of Construction Technology and Management, Vilnius Gediminas Technical \\ University, Sauletekio al. 11, LT-10223 Vilnius, Lithuania \\ E-mail: modestas.kracka@vgtu.lt \\ ${ }^{2}$ Department of Construction Technology and Management, Vilnius Gediminas Technical \\ University, Sauletekio al. 11, LT-10223 Vilnius, Lithuania \\ E-mail: edmundas.zavadskas@vgtu.lt
}

Received 31 December 2012; accepted 4 April 2013

\begin{abstract}
Sustainable development has taken on a new concept: building maintenance, materials production, buildings demolition to determine the amount of energy and resources. This paper presents the process of effective selection of building elements for renovation which are important for energy effectiveness of buildings. Multi-criteria MOORA and MULTIMOORA methods has been adapt for problems solving with interval data. The paper presents a theoretical model of practice design renovation solutions evaluated. The theoretical model can also be applied to practical solutions to assess new construction planning stage, and other life-building processes.
\end{abstract}

KEYWORDS: Multi-attribute decision making; MOORA method; MULTIMOORA method; Interval fuzzy data; Building refurbishment

REFERENCE to this paper should be made as follows: Kracka, M. and Zavadskas, E. K. (2013) Panel building refurbishment elements effective selection by applying multiple-criteria methods, International Journal of Strategic Property Management, 17(2), pp. 210-219.

\section{INTRODUCTION}

Construction is one of the major industries in which sustainable development is developing rapidly (Konstantinou and Knaack, 2011; Bojic et al., 2012). At present time, special attention is allocated to residential and public buildings renovation processes. According to EU directives, refurbishment process will accelerate and will continue until 2020, when all new and reconstructed buildings will be zero energy consumption. Most dwelling-houses in Lithuania were built in 1960-1990. Although heating costs were high, the costs were not as high as they are presently. Therefore the energy performance category of the dwellinghouses built is low. According to the Lithuanian regulation Requirement (STR 2.01.09, 2005), the energy performance of a building is the amount of energy, which is expressed by a building energy performance class, required when a building is to be used as a dwelling. The energy performance class of a building, or part of a building, is determined according the value of a qualifying indicator and the requirements of the Lithuanian Regulation Requirement (STR. 2.01.09, 2005). It should be noted that during building design, necessary to assess: environmental, architectural, design and engineering factors, which will impact living 




Figure 1. The model of sustainable buildings refurbishment

condition in the future (Kalibatas et al., 2012; Hong et al., 2009).

The main results, expected from public buildings refurbishment, are (Mickaityte et al., 2008; Short et al., 2010):

- Energy savings;

- Increase of comfort;

- Healthy working environment assurance;

- Extension of building life cycle;

- Economized exploitation;

- Environment protection.

After building reconstruction, generated property value during exploitation time is increasing, but expenses during exploitation time are decreasing. Property value decreasing intensity depends on the characteristics of the materials used in their durability, design, technical solutions, building maintenance and intensity during operation (Falk et al., 2009). During reconstruction, worn out structures are changing to new ones, but over time sets the limit of the building restoration value is economically expedient (see Figure 1) (Venckus et al., 2012; Zavadskas et al., 2009a).

In some cases, building value after refurbishment could be increased, but with time, after second refurbishment process value will not reach up the initial value (Figure 2) - it is important to mention that building is not classified as heritage building and is not considered a building location.

Normally residential and public buildings envelope lifetime are 50 years, engineering systems 30 years, for bridges, viaducts durability assessed 80 years. Lifetime is given according to building intended use and constructed material type: residential large- panel building life time is 100 years, residential monolith building 120 years, brick or mixed structure building life time is 100 years (STR 1.12.06:2002). Most of the buildings were built in Lithuania during period of 40 years, some structures of building are already obsolete, and therefore it is necessary change to new once. Currently most buildings in Lithuania are in period before renovation stage $-t_{1}$. Where $t_{r 1}$ - is building renovation duration; $t_{2}$ - building lifetime after renovation. Next chart lines indicates $t_{n}$ building life cycle after renovation and $t_{r 2}$ replicated building renovation. Therefore, it is very important before the renovation process, to clarify which structures

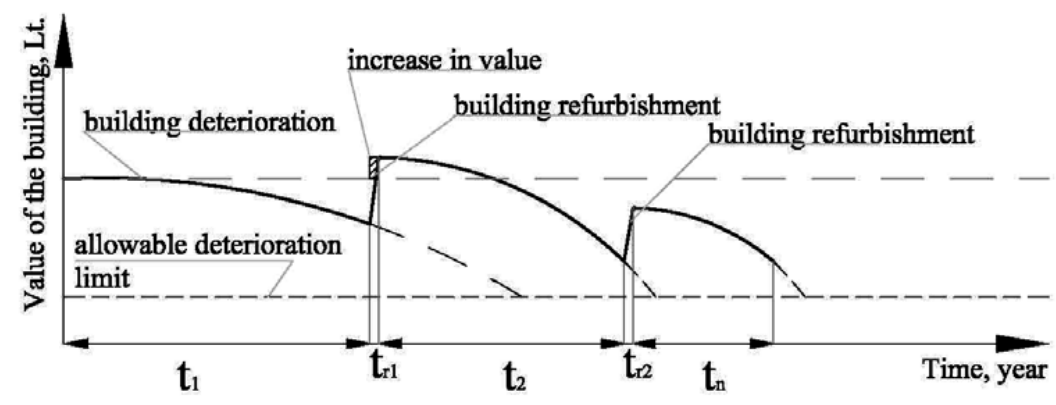

Figure 2. Building depreciation timetable 
(alternatives) should be changed and further to select most suitable insulation layer type (Golic et al., 2011; Atkinson et al., 2009). The authors have developed a conceptual model for sustainable refurbishment of buildings. The model was created basing on sustainable in decision-making processes and on the factors which influence the model's efficiency.

Multi-criteria decision making methods help to assess all alternatives at the same time. Although using multi criteria decision methods alternatives cannot be determined precisely, therefore authors have suggested to express criteria's in the form of intervals (Zavadskas et al., 2009b; Chatterjee and Chakraborty, 2012; Maity et al., 2012). After expression interval values should be calculated using Multi-Objective Optimization on the basis of Ratio Analysis (MOORA) method (Brauers and Zavadskas, 2006). During the intermediate calculation action, value from rational interval should be selected and recalculated using MOORA and MULTIMOORA methods (Brauers and Zavadskas, 2010; Bitarafan et al., 2012).

\section{A METHOD OF MULTI-}

\section{ALTERNATIVE ASSESSMENT USING MOORA METHOD WITH INTERVAL DATA}

In order to check a larger number of parameters and options, the author of the data defined intervals. Later, re-applied the algorithmic ac- tion again and recalculate values but only with an optimal range of existing values. All calculations were made using MOORA and MULTIMOORA methods (Brauers and Zavadskas, 2006). In accordance with Chakraborty (2011) MOORA method (Table 1) is more applicability, potentiality and flexibility in comparison with Analytic Hierarchy Process (AHP) (Saaty, 1990), Technique for Order Preference by Similarity to an ideal solution (TOPSIS) (Hwang and Yoon, 1981), VIKOR (VlseKriterijumslca Optimizacija) (Opricovic and Tzeng, 2004), Preference Ranking Organization METHod for Enrichment Evaluations (PROMETHEE) (Brans et al., 1984) and ELimination and Choice Expressing REality (ELECTRE) (Roy, 1968).

Multi-Objective by Ratio Analysis (MOORA) was introduced by Brauers and Zavadskas in 2006, later these authors have extended the method to MULTIMOORA (Brauers and Zavadskas, 2010). These methods have been mentioned in different type of the world problem decisions, starting from investment management, construction, property management and etc. (Brauers et al., 2012).

According to Chen (1985), the decisionmaking systems, the theory of intervals, interval values can be defined:

1. An integer expresses the exact information $x^{\prime}=x^{\prime \prime}$;

2. Contingent figure - does not signify any information $x^{\prime} \rightarrow \infty$ and $x^{\prime \prime} \rightarrow \infty$;

3 . Number in the range $\left[x^{\prime} ; x^{\prime \prime}\right]$.

Table 1. Comparative performance of some popular MODM methods (Chakraborty, 2011)

\begin{tabular}{llllll}
\hline MODM method & $\begin{array}{l}\text { Computational } \\
\text { time }\end{array}$ & Simplicity & $\begin{array}{l}\text { Mathematical } \\
\text { calculations } \\
\text { involved }\end{array}$ & Stability & $\begin{array}{l}\text { Information } \\
\text { type }\end{array}$ \\
\hline MOORA & Very less & Very simple & Minimum & Good & Quantitative \\
AHP & Very high & Very critical & Maximum & Poor & Mixed \\
TOPSIS & Moderate & Moderately critical & Moderate & Medium & Quantitative \\
VIKOR & Less & Simple & Moderate & Medium & Quantitative \\
ELECTRE & High & Moderately critical & Moderate & Medium & Mixed \\
PROMETHEE & High & Moderately critical & Moderate & Medium & Mixed \\
\hline
\end{tabular}


An integer

values

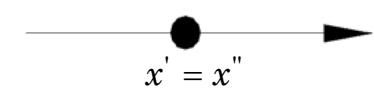

Undefined values of indicators

Indicator values in range

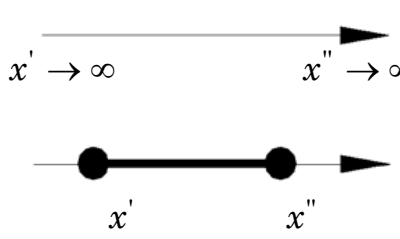

An interval fuzzy number is fully characterized by a pair of real numbers $\left(x_{1}^{\prime}, x_{2}^{\prime}\right)$ Where $x_{1}^{\prime}$ and $x_{2}^{\prime}$ are the lower and upper bounds. A fuzzy number $\bar{A}=\left(x_{1}^{\prime}, x_{2}^{\prime}\right)$ is shown on Figure 3.

$$
\otimes x=\left[x^{\prime}, x^{\prime \prime}\right]=\left[x^{\prime} \in x \mid \underline{x^{\prime} \leq x \leq x^{\prime \prime}}\right]
$$

Authors review basic definitions of fuzzy sets and fuzzy numbers for the purpose of representing the proposed algorithm.

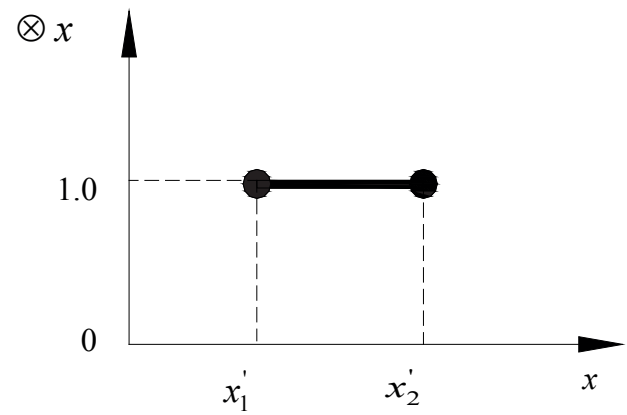

Figure 3. Membership function of fuzzy number $\bar{A}=\left(x_{1}^{\prime}, x_{2}^{\prime}\right)$ (Stanujkic et al., 2011)

An interval number is characterized by a pair of numbers $x_{1}^{\prime}$ and $x_{2}^{\prime}$. Where lower value is $x_{1}^{\prime}$ and bigger value is $x_{2}^{\prime} .\left(x_{1}^{\prime}, x_{2}^{\prime} \in \Re ; x_{1}^{\prime}<x_{2}^{\prime}\right)$. The membership function $\otimes x$ is thus defined as:

$$
\otimes x=\left\{\begin{array}{l}
1, x \in\left[x_{1}{ }^{\prime}, x_{2}{ }^{\prime}\right], \\
0, \text { otherwise. }
\end{array}\right.
$$

Let $\bar{A}$ and $\bar{B}$ are two positive fuzzy numbers. The main algebraic operations of any two positive fuzzy numbers can be defined in the following way (Moore, 1966):

Addition:

$$
\bar{A} \oplus \bar{B}=\left[x_{1}^{\prime}, x_{2}^{\prime}\right] \oplus\left[x_{1}^{\prime \prime}, x_{2}^{\prime \prime}\right]=\left(x_{1}^{\prime}+x_{1}^{\prime \prime}, x_{2}^{\prime}+x_{2}{ }_{2}\right) \text {; }
$$

Subtraction:

$$
\bar{A}-\bar{B}=\left[x_{1}^{\prime}, x_{2}^{\prime}\right]-\left[x_{1}{ }_{1}, x_{2}{ }_{2}\right]=\left(x_{1}^{\prime}-x_{1}{ }_{1}, x_{2}^{\prime}-x_{2}\right) \text {; }
$$

Multiplication:

$$
\bar{A} \otimes \bar{B}=\left[x_{1}^{\prime}, x_{2}^{\prime}\right] \otimes\left[x_{1}{ }_{1}, x_{2}{ }_{2}\right]=\left(x_{1}^{\prime} \times x_{1}^{\prime \prime}, x_{2}^{\prime} \times x_{2}{ }_{2}\right) \text {; }
$$

Division:

$$
\bar{A} / \bar{B}=\left[x_{1}^{\prime}, x_{2}^{\prime}\right] /\left[x_{1}^{\prime \prime}, x_{2}^{\prime \prime}\right]=\left(x_{1}^{\prime} / x_{1}^{\prime \prime}, x_{2}^{\prime} / x_{2}^{\prime \prime}\right) \text {; }
$$

Multiplication by real number $k$ :
$\bar{A}=\left(x_{1}^{\prime}, x_{2}^{\prime}\right)$ a nd $\bar{B}=\left(x_{1}{ }^{\prime \prime}, x_{2}^{\prime \prime}\right)$ then, the distance between two bands and the center will be given by the following formula:

\subsection{Ratio system with interval data of} Multiple criteria method connection with interval system helps to approve a large amount of information (Baležentis and Zeng, 2013; and we only know their minimum $x_{1}^{\prime}$ and maximum $x_{1}^{\prime \prime}$ values, which are also the lower and upper interval boundaries. Interval data $x_{i j}^{\prime} \in\left[x_{i j}^{\prime}, x_{i j}^{\prime \prime}\right]$ concisely expressed in matrix as:

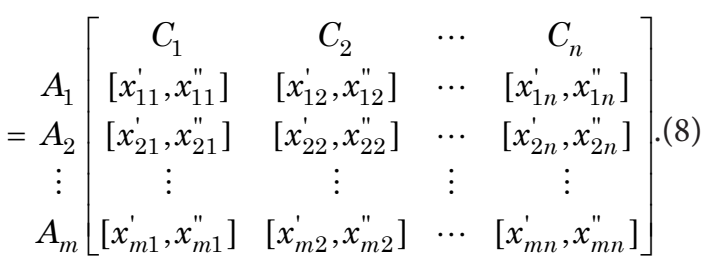

where: the normalized value in the range of the $x_{i j}^{\prime}$ minimum and $x_{i j}^{\prime \prime}$ maximum range.

$$
\overline{x_{i j}^{\prime \prime}}=\frac{x_{i j}^{\prime \prime}}{\sqrt{\sum_{j=1}^{m}\left(x_{i j}^{\prime}\right)^{2}+\sum_{j=1}^{m}\left(x_{i j}^{\prime \prime}\right)^{2}}} ;
$$


where: $x_{i j}-i=\overline{1, n} ; \quad j=\overline{1, m}$. The normalized values include in interval $[0 ; 1]$. The indicators are aggregated - if the values are maximized, or reduced - if the values are minimized. If the method is used for significance of indicators, their use would be carried out after normalization parameters.

To calculate the upper limits of the intervals, which represent the overall rating of benefit criteria $S_{i}^{+}$are using below mention formulas:

$$
\begin{aligned}
& s_{i}^{+x^{\prime}}=\sum_{j=1}^{n} \overline{x_{i j}^{\prime}} \mid j \in J^{\max }, \\
& s_{i}^{+x^{\prime \prime}}=\sum_{j=1}^{n} \overline{x_{i j}^{\prime \prime}} \mid j \in J^{\max },
\end{aligned}
$$

where: $S_{i}^{+x^{\prime}}$ and $S_{i}^{+x^{\prime \prime}}$ are values of lower and upper limits of intervals.

$$
\begin{aligned}
& s_{i}^{-x^{\prime}}=\sum_{j=1}^{n} \overline{x_{i j}^{\prime}} \mid j \in J^{\max }, \\
& s_{i}^{-x^{\prime \prime}}=\sum_{j=1}^{n} \overline{x_{i j}^{\prime}} \mid j \in J^{\max },
\end{aligned}
$$

where: $S_{i}^{-x^{\prime}}$ and $S_{i}^{-x^{\prime \prime}}$ are values of lower and upper bounds of intervals. In order to specify accurate alternatives in intermediate interval calculation, new arithmetic action was adapted for new purpose. In next step using arithmetic average result is recalculating of pervious steps - maximizes and minimizes ranges of values.

$$
S_{i}\left(S_{i}^{+}, S_{i}^{-}\right)=\frac{1}{2}\left[\left(s_{i}^{+x^{\prime}}-s_{i}^{-x^{\prime}}\right)+\left(s_{i}^{+x^{\prime \prime}}-s_{i}^{-x^{\prime \prime}}\right)\right] .
$$

Sequence principle alternatives are arranged in descending order corresponding to receive calculation results. The most effective option would be the value of the maximum.

\subsection{The reference point with interval data}

The fuzzy reference point approach is based on the fuzzy ratios. Every element of the ratio matrix is recalculated and final rank is given according to deviation from the reference point and Min-Max Metric of Tchebycheff (Karlin and Studden, 1966, p. 280).

$$
\min _{(j)}\left\{\max _{(i)}\left|r_{i}-\overline{x_{i j}^{*}}\right|\right\},
$$

where: $i=1,2 \ldots, n$ are the objective; $j=1,2, \ldots, m$ are the alternatives; $r_{i}-$ the $i^{\text {th }}$ co-ordinate of the maximal objective reference point; each coordinate of the reference point is selected as the highest corresponding co-ordinate of the alternative; $\overline{x_{i j}}$ - the normalized objective $i$ of alternative $j$.

\subsection{The full multiplicative form with interval data}

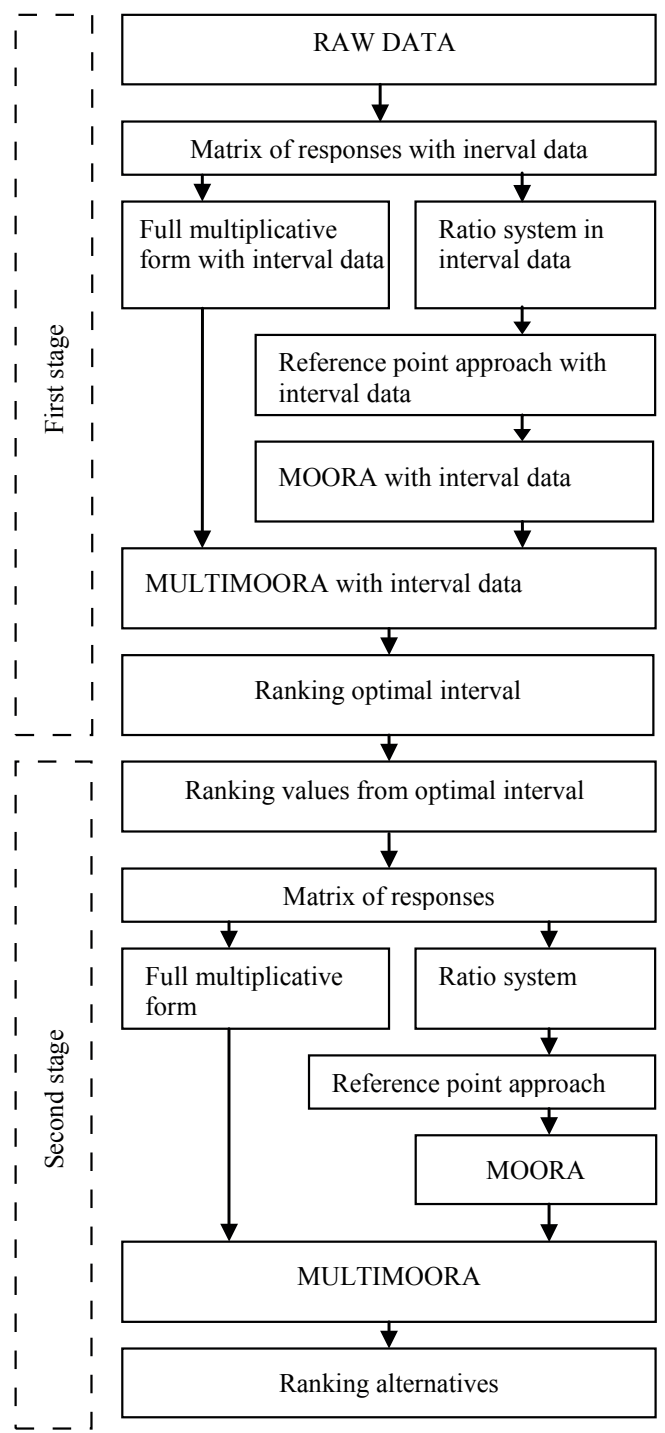

Figure 4. A graphical MULTIMOORA with interval data block 
Utility of the $i$-th alterative can be expressed as dimensionless number:

$$
U_{j}=\prod_{i=1}^{n} \frac{x_{i j}^{\prime}+x_{i j}^{\prime \prime}}{2},
$$

where: $j=1,2, \ldots, m$; $m$ the number of alternatives; $i=1,2, \ldots, n$; $n$ being the number of objectives; $x_{i j}^{\prime}$ - the lower interval value, $x_{i j}^{\prime}-$ is higher interval value responses of alternative $j$ to objective $i$; $U_{j}$ overall utility of alternative $j$.

After rational results reception from interval data, values are recalculated again using MOORA and MULTIMOORA methods.

In the first stage values are selected and sorted into intervals (see Figure 4). Until it is unknown the exact range of accessories, values ranged can be provided in your own. Using MOORA and MULTIMOORA method with intervals values are calculated and ranked optimal interval. In the second stage values are selected from the optimal interval and filled in the matrix for further calculation with MOORA and MULTIMOORA methods.

\section{APPLICATION MOORA AND MULTIMOORA METHODS WITH INTERVAL DATA TO ASSESSMENT OF PANEL BUILDING REFURBISHMENT}

Panel buildings in Lithuania were built during last 40 years period. The thermal insulation performance, microclimate, relative humidity, air movement of such building is rather poor and does not comply with the current Lithuanian hygienic requirements (HN 42:2004). The main important areas are situated along the wall and slab juncture (Biekša et al., 2011; Zavadskas et al., 2008). Authors will consider a numerical example in order to explain the panel buildings refurbishment using multi criteria method with intervals. Heating energy losses and inflows were calculated using equations from the technical construction regulation (STR 2.05.01:2005). A five storey building was selected for the analysis. From a ceiling to a ceiling, the height of a storey is $2.85 \mathrm{~m}$. The building has 90 windows in total. 45 windows face north and the remaining 45 - face south. The building is naturally ventilated. Heating in the building is supplied through heat networks from the central heating boiler- house of the city.

Table 2 shows building envelope assessment options. Building walls assessment depends on the: thermal resistance, structure refurbishment price, energy savings, payback time. Because of the lack of free space, was selected wall assessment example. Final building assessment are calculating using all building structures (roof, windows, doors, cellars, thermal bridges, etc.) and engineering systems (heating, cooling, ventilation), but using the same method for final results calculation.

Table 2. Raw data

\begin{tabular}{|c|c|c|c|c|c|c|c|}
\hline \multirow{4}{*}{$\begin{array}{l}\text { Partition } \\
\text { name }\end{array}$} & \multicolumn{7}{|l|}{ Criteria } \\
\hline & $\begin{array}{l}\text { Thermal } \\
\text { resistance }\end{array}$ & $\begin{array}{l}\text { Structure } \\
\text { refurbishment } \\
\text { price }\end{array}$ & $\begin{array}{l}\text { Prices for } \\
\text { the entire } \\
\text { area }\end{array}$ & $\begin{array}{l}\text { After } \\
\text { refurbishment } \\
\text { saved energy } \\
\text { consumptions }\end{array}$ & $\begin{array}{l}\text { Savings } \\
\text { per year }\end{array}$ & $\begin{array}{l}\text { Losses } \\
\text { Euros } \\
\text { per year }\end{array}$ & $\begin{array}{l}\text { Payback } \\
\text { time }\end{array}$ \\
\hline & $\left(m^{2} \times K\right) / K$ & euro $/ m^{2}$ & euro & $\left(W h / m^{2} \times\right.$ year $)$ & euro & euro & years \\
\hline & $\max$ & $\min$ & $\min$ & $\max$ & $\max$ & $\min$ & $\min$ \\
\hline $\begin{array}{l}\text { Existing } \\
\text { wall value }\end{array}$ & 0,90 & 0,00 & 0,00 & 45,59 & 0,00 & 5658,31 & 0,00 \\
\hline $\mathrm{A} 1$ & 2,00 & 80,00 & 114892,80 & 25,25 & 2525,08 & 3133,23 & 45,50 \\
\hline $\mathrm{A} 2$ & 3,00 & 90,00 & 129254,40 & 16,81 & 3571,60 & 2086,71 & 36,19 \\
\hline A3 & 4,00 & 95,00 & 136435,20 & 12,62 & 4091,63 & 1566,68 & 33,34 \\
\hline $\mathrm{A} 4$ & 5,00 & 100,00 & 143616,00 & 10,10 & 4404,77 & 1253,54 & 32,60 \\
\hline A5 & 6,00 & 110,00 & 157977,60 & 8,43 & 4612,04 & 1046,27 & 34,25 \\
\hline A6 & 6,50 & 120,00 & 172339,20 & 7,78 & 4692,71 & 965,60 & 36,72 \\
\hline
\end{tabular}


Table 3. Matrix with interval normalization

\begin{tabular}{|c|c|c|c|c|c|c|}
\hline \multirow{6}{*}{$\begin{array}{l}\text { Partition } \\
\text { name }\end{array}$} & \multicolumn{6}{|l|}{ Criteria } \\
\hline & $\begin{array}{l}\text { Thermal } \\
\text { resistance }\end{array}$ & $\begin{array}{l}\text { Prices for the } \\
\text { entire area }\end{array}$ & $\begin{array}{l}\text { After refurbishment } \\
\text { saved energy } \\
\text { consumptions }\end{array}$ & $\begin{array}{l}\text { Savings per } \\
\text { year }\end{array}$ & $\begin{array}{l}\text { Losses Euros } \\
\text { per year }\end{array}$ & Payback time \\
\hline & $\left(m^{2} \times K\right) / K$ & euro $/ \mathrm{m}^{2}$ & $\left(W h / m^{2} \times\right.$ year $)$ & euro & euro & years \\
\hline & $\otimes x_{1}$ & $\otimes x_{2}$ & $\otimes x_{3}$ & $\otimes x_{4}$ & $\otimes x_{5}$ & $\otimes x_{6}$ \\
\hline & $x_{1}^{\prime \prime}$ & $x_{2}^{\prime}$ & $x_{3}^{\prime}$ & $x_{4}^{\prime \prime}$ & $x_{5}^{\prime \prime}$ & $x_{6}^{\prime}$ \\
\hline & $\max$ & $\min$ & $\max$ & $\max$ & $\min$ & $\min$ \\
\hline $\mathrm{A} 1$ & {$[0,90 ; 2,00]$} & $\begin{array}{l}{[0,00 ;} \\
114892,80]\end{array}$ & {$[0,00 ; 20,35]$} & $\begin{array}{l}{[0,00 ;} \\
2525,08]\end{array}$ & $\begin{array}{l}{[5658,31 ;} \\
3133,23]\end{array}$ & {$[0,00 ; 45.50]$} \\
\hline A2 & {$[2,00 ; 3,00]$} & $\begin{array}{l}{[114892,80 ;} \\
122073,60]\end{array}$ & {$[20,35 ; 28,78]$} & $\begin{array}{l}{[2525,0 ;} \\
3571,60]\end{array}$ & $\begin{array}{l}{[3133,23 ;} \\
2086,71]\end{array}$ & {$[45,50 ; 34,18]$} \\
\hline A3 & {$[3,00 ; 4,00]$} & $\begin{array}{l}{[122073,60 ;} \\
134999,04]\end{array}$ & {$[28,78 ; 32,97]$} & $\begin{array}{l}{[3571,6 ;} \\
4091,63]\end{array}$ & $\begin{array}{l}{[2086,71 ;} \\
1566,68]\end{array}$ & {$[34,18 ; 32,99]$} \\
\hline A4 & {$[4,00 ; 5,00]$} & $\begin{array}{l}{[134999,04} \\
146488,32]\end{array}$ & {$[32,97 ; 35,49]$} & $\begin{array}{l}{[4091,6 ;} \\
4404,77]\end{array}$ & $\begin{array}{l}{[1566,68} \\
1253,54]\end{array}$ & {$[32,99 ; 33,26]$} \\
\hline A5 & {$[5,00 ; 6,00]$} & $\begin{array}{l}{[146488,32 ;} \\
160849,92]\end{array}$ & {$[35,49 ; 37,16]$} & $\begin{array}{l}{[4404,7 ;} \\
4612,04]\end{array}$ & $\begin{array}{l}{[1253,54} \\
1046,27]\end{array}$ & {$[33,26 ; 34,88]$} \\
\hline A6 & {$[6,00 ; 6,50]$} & $\begin{array}{l}{[160849,92 ;} \\
175211,52]\end{array}$ & {$[37,16 ; 37,81]$} & $\begin{array}{l}{[4612,0 ;} \\
4692,71]\end{array}$ & $\begin{array}{l}{[1046,27} \\
965,60]\end{array}$ & {$[34,88 ; 37,34]$} \\
\hline
\end{tabular}

Table 4. Normalized decision-making matrix

\begin{tabular}{lllllll}
\hline & $\otimes x_{1}$ & & & & & $\otimes x_{3}$ \\
& $x_{1}^{\prime}$ & $x_{1}^{\prime \prime}$ & $x_{2}^{\prime}$ & $x_{2}^{\prime \prime}$ & $x_{3}^{\prime}$ & $x_{3}^{\prime \prime}$ \\
\cline { 2 - 7 } & Pessimistic & Optimistic & Pessimistic & Optimistic & Pessimistic & Optimistic \\
\hline A1 & 0,095 & 0,210 & 0,000 & 0,375 & 0,000 & 0,289 \\
A2 & 0,210 & 0,315 & 0,375 & 0,399 & 0,289 & 0,408 \\
A3 & 0,315 & 0,420 & 0,399 & 0,441 & 0,408 & 0,468 \\
A4 & 0,420 & 0,525 & 0,441 & 0,479 & 0,468 & 0,503 \\
A5 & 0,525 & 0,630 & 0,479 & 0,526 & 0,503 & 0,527 \\
A6 & 0,630 & 0,682 & 0,526 & 0,573 & 0,527 & 0,536 \\
\hline & $\otimes x_{4}$ & & $\otimes x_{5}$ & & $0 x_{6}$ & \\
& $x_{4}^{\prime}$ & $x_{4}^{\prime \prime}$ & $x_{5}^{\prime}$ & $x_{5}^{\prime \prime}$ & $x_{6}^{\prime}$ & $x_{6}^{\prime \prime}$ \\
\cline { 2 - 7 } & Pessimistic & Optimistic & Optimistic & Pessimistic & Optimistic & Pessimistic \\
\hline A1 & 0,095 & 0,210 & 0,000 & 0,375 & 0,000 & 0,289 \\
A2 & 0,210 & 0,315 & 0,375 & 0,399 & 0,289 & 0,408 \\
A3 & 0,315 & 0,420 & 0,399 & 0,441 & 0,408 & 0,468 \\
A4 & 0,420 & 0,525 & 0,441 & 0,479 & 0,468 & 0,503 \\
A5 & 0,525 & 0,630 & 0,479 & 0,526 & 0,503 & 0,527 \\
A6 & 0,630 & 0,682 & 0,526 & 0,573 & 0,527 & 0,536 \\
\hline
\end{tabular}

Table 5. Ranking efficient interval

\begin{tabular}{lllll}
\hline \multirow{2}{*}{$\begin{array}{l}\text { Partition } \\
\text { name }\end{array}$} & \multicolumn{2}{l}{ MOORA method with interval } & $\begin{array}{l}\text { Full multiplicative } \\
\text { form with interval }\end{array}$ & MULTIMOORA \\
\cline { 2 - 4 } & $\begin{array}{l}\text { Ratio system with } \\
\text { interval }\end{array}$ & $\begin{array}{l}\text { Reference point with } \\
\text { interval }\end{array}$ & $\mathbf{6}$ & 6 \\
\hline A1 & 6 & $\mathbf{6}$ & $\mathbf{5}$ & 5 \\
A2 & 2 & $\mathbf{5}$ & $\mathbf{4}$ & 2 \\
A3 & 1 & $\mathbf{2}$ & $\mathbf{3}$ & 1 \\
A4 & 3 & $\mathbf{1}$ & $\mathbf{2}$ & 3 \\
A5 & 4 & $\mathbf{3}$ & $\mathbf{1}$ & 4 \\
A6 & 5 & $\mathbf{4}$ & & \\
\hline
\end{tabular}


Table 5. Ranking efficient intervals 3, 4 and 5 show intermediate results of multi criteria calculation with intervals. We are selecting interval between values A4 to A3. Interval upper boundary is A4 $=5.0$ and interval lower boundary is $\mathrm{A} 3=4.0$. In our case it is enough to select values in two hundred precision. In the next step using multi criteria methods MOORA and MULTIMOORA will be ranked the most efficient alternative (see Table 6).

According to the calculation results (Table 7), ranking order of alternatives is as follows: $\mathrm{A} 4 \succ \mathrm{A} 5 \succ \mathrm{A} 3 \succ \mathrm{A} 2 \succ \mathrm{A} 1$. This means that the best alternative in sleeted interval is A4 with thermal resistance value $4.6\left(m^{2} \times K\right) / K$, the worst alternative with the result $4.0\left(\mathrm{~m}^{2} \times\right.$ K) / $K$.

In such way also were calculated other building partitions values: roof, windows, cellar, doors as well as in example in this paper (see Table 8). This way is the best solution to calculate effective partitions alternatives in building refurbishment process. Model can be easily extended to provide usage of the interval data numbers (Rezaeiniya et al., 2012; Hajiagha et al., 2012).

Table 6. Selected values from efficient interval

\begin{tabular}{lllllll}
\hline $\begin{array}{l}\text { Partition } \\
\text { name }\end{array}$ & $\begin{array}{l}\text { Thermal } \\
\text { resistance }\end{array}$ & $\begin{array}{l}\text { Structure } \\
\text { refurbishment } \\
\text { price }\end{array}$ & $\begin{array}{l}\text { After refurbishment } \\
\text { saved energy } \\
\text { consumptions }\end{array}$ & $\begin{array}{l}\text { Savings } \\
\text { per year }\end{array}$ & $\begin{array}{l}\text { Losses } \\
\text { Euros per } \\
\text { year }\end{array}$ & $\begin{array}{l}\text { Payback } \\
\text { time }\end{array}$ \\
\cline { 2 - 7 } & $\begin{array}{l}\left(m^{2} \times K\right) / K \\
\max \end{array}$ & euro $/ m^{2}$ & $\begin{array}{l}\left(\text { Wh } / m^{2} \times \text { year }\right) \\
\max \end{array}$ & euro & euro & year \\
& $x_{1}$ & $x_{2}$ & $x_{3}$ & $x_{4}$ & $x_{5}$ & $x_{6}$ \\
\hline A1 & 4,00 & 134999,04 & 32,97 & 4092,00 & 1566,31 & 32,991 \\
A2 & 4,20 & 137871,36 & 33,57 & 4166,47 & 1491,84 & 33,091 \\
A3 & 4,40 & 140743,68 & 34,13 & 4235,97 & 1422,33 & 33,226 \\
A4 & 4,60 & 143616,00 & 34,63 & 4298,03 & 1360,28 & 33,414 \\
A5 & 4,80 & 146488,32 & 35,09 & 4355,12 & 1303,19 & 33,636 \\
\hline
\end{tabular}

Table 7. Ranking the most efficient alternatives

\begin{tabular}{lllll}
\hline \multirow{2}{*}{$\begin{array}{l}\text { Partition } \\
\text { name }\end{array}$} & \multicolumn{2}{l}{ MOORA method } & $\begin{array}{l}\text { Full multiplicative } \\
\text { form with interval }\end{array}$ & MULTIMOORA \\
\cline { 2 - 5 } & Ratio system & Reference point with interval & \\
\hline A1 & 5 & 5 & 5 & 6 \\
A2 & 2 & 4 & 4 & 5 \\
A3 & 1 & 3 & 3 & 3 \\
A4 & 3 & 1 & 2 & 1 \\
A5 & 4 & 2 & 1 & 2 \\
\hline
\end{tabular}

Table 8. Most effective building partitions results

\begin{tabular}{|c|c|c|c|c|c|c|c|c|}
\hline \multirow{2}{*}{$\begin{array}{l}\text { Partition } \\
\text { name }\end{array}$} & \multicolumn{2}{|l|}{ walls } & \multicolumn{2}{|l|}{ roof } & \multicolumn{2}{|c|}{ cellar ceilings } & \multicolumn{2}{|l|}{ windows } \\
\hline & $\left(m^{2} \times K\right) / K$ & $\begin{array}{l}\text { Verse. } \\
\text { No }\end{array}$ & $\left(m^{2} \times K\right) / K$ & $\begin{array}{l}\text { Verse. } \\
\text { No }\end{array}$ & $\left(m^{2} \times K\right) / K$ & $\begin{array}{l}\text { Verse. } \\
\text { No }\end{array}$ & $\left(m^{2} \times K\right) / K$ & $\begin{array}{l}\text { Verse. } \\
\text { No }\end{array}$ \\
\hline A1 & 4,00 & 6 & 5,00 & 6 & 5,00 & 5 & 0,59 & 2 \\
\hline $\mathrm{A} 2$ & 4,20 & 5 & 5,20 & 5 & 5,20 & 4 & 0,59 & 3 \\
\hline A3 & 4,40 & 3 & 5,40 & 1 & 5,40 & 2 & 0,50 & 5 \\
\hline $\mathrm{A} 4$ & 4,60 & 1 & 5,60 & 2 & 5,60 & 1 & 0,50 & 4 \\
\hline A5 & 4,80 & 2 & 5,80 & 3 & 5,80 & 3 & 0,50 & 1 \\
\hline
\end{tabular}




\section{CONCLUSION}

With the help of multi-objective decisionmaking methods, the investigation aims were made to create a technique for an effective selection of insulation and further refurbishment process, for panel building structures, by applying MOORA and MULTIMOORA methods with intervals and new algorithmic action. The experimental data and presented results in this paper show that the proposed method can be used to evaluate building refurbishment and to determine does it meet standards. This study proved that the proposed theoretical model was effective in real life and could be successfully applied for a solution of similar utility problems in construction as well as in other fields.

\section{REFERENCES}

Atkinson, J. G. B., Jackson, T. and Mullings-Smith, E. (2009) Market influence on the low carbon energy refurbishment of existing multi-residential buildings, Energy Policy, 37(7), pp. 2582-2593. http://dx.doi. org/10.1016/j.enpol.2009.02.025

Baležentis, A., Baležentis, T. and Brauers, W. K. M. (2012) Personnel selection based on computing with words and fuzzy MULTIMOORA, Expert Systems with Applications, 39(9), pp. 7961-7967. http://dx.doi. org/10.1016/j.eswa.2012.01.100

Baležentis, T. and Zeng, S. Z. (2013) Group multi-criteria decision making based upon interval-valued fuzzy numbers: An extension of the MULTIMOORA method, Expert Systems with Applications, 40(2), pp. 543-550. http://dx.doi.org/10.1016/j.eswa.2012.07.066

Biekša, D., Šiupšinskas, G., Martinaitis, V. and Jaraminiené, E. (2011) Energy efficiency challenges in multi-apartment building renovation in Lithuania, Journal of Civil Engineering and Management, 17(4), pp. 467-475. http://dx.doi.org/10.3846/1392373 0.2011 .622408

Bitarafan, M., Zolfani, S. H., Arefi, S. L. and Zavadskas, E. K. (2012) Evaluating the construction methods of cold-formed steel structures in reconstructing the areas damaged in natural crises, using the methods AHP and COPRAS-G, Archives of Civil and Mechanical Engineering, 12(3), pp. 360-367. http:// dx.doi.org/10.1016/j.acme.2012.06.015

Bojic, M., Djordjevic, S., Stefanovic, A., Miletic, M. and Cvetkovic, D. (2012) Decreasing energy consumption in thermally non-insulated old house via refurbishment, Energy and Buildings, 54, pp. 503-510. http:// dx.doi.org/10.1016/j.enbuild.2012.03.045
Brans, J. P., Mareschal, B. and Vincke, Ph. (1984) PROMETHEE: A new family of outranking methods in multicriteria analysis. In: Brans, J. P. (ed.), Operational Research '84. North-Holland, New York, pp. 477-490.

Brauers, W. K. M. and Zavadskas, E. K. (2006) The MOORA method and its application to privatization in a transition economy, Control and Cybernetics, 35(2), pp. 445-469.

Brauers, W. K. M. and Zavadskas, E. K. (2010) Project management by MULTIMOORA as an instrument for transition economies, Technological and Economic Development of Economy, 16(1), pp. 5-24. http:// dx.doi.org/10.3846/tede.2010.01

Brauers, W. K. M., Kracka, M. and Zavadskas, E. K. (2012) Lithuanian case study of masonry buildings from the Soviet period, Journal of Civil Engineering and Management, 18(3), pp. 444-456. http://dx.doi.or $\mathrm{g} / 10.3846 / 13923730.2012 .700944$

Chakraborty, S. (2011) Applications of the MOORA method for decision making in manufacturing environment, International Journal of Advanced Manufacturing Technology, 54(9-12), pp. 1155-1166. http:// dx.doi.org/10.1007/s00170-010-2972-0

Chatterjee, P. and Chakraborty, S. (2012) Material selection using preferential ranking methods, Materials \& Design, 35, pp. 384-393. http://dx.doi.org/10.1016/j. matdes.2011.09.027

Chen, S. H. (1985) Ranking fuzzy numbers with maximizing set and minimizing set, Fuzzy Sets and Systems, 17(2), pp. 113-129. http://dx.doi.org/10.1016/01650114(85)90050-8

Falk, H., Wijk, H. and Persson, L. O. (2009) The effects of refurbishment on residents' quality of life and wellbeing in two Swedish residential care facilities, Health \& Place, 15(3), pp. 717-724. http://dx.doi. org/10.1016/j.healthplace.2008.11.004

Golic, K., Kosoric, V. and Furundzic, A. K. (2011) General model of solar water heating system integration in residential building refurbishment-potential energy savings and environmental impact, Renewable and Sustainable Energy Reviews, 15(3), pp. 1533-1544. http://dx.doi.org/10.1016/j.rser.2010.11.052

Hajiagha, S. H. R., Hashemi, S. S., Zavadskas, E. K. and Akrami, H. (2012) Extensions of LINMAP model for multi criteria decision making with grey numbers, Technological and Economic Development of Econo$m y, 18(4)$, pp. 636-650. http://dx.doi.org/10.3846/202 94913.2012.740518

HN 42:2004 (2004) Residential and public buildings microclimate. Lithuanian Hygiene Standard. Lithuania, 2004.

Hong, S. H., Gilbertson, J., Oreszczyn, T., Green, C. and Ridley, I. (2009) A field study of thermal comfort in low-income dwellings in England before and after energy efficient refurbishment, Building and Environment, 44(6), pp. 1228-1236. http://dx.doi. org/10.1016/j.buildenv.2008.09.003 
Hwang, C. L. and Yoon, K. (1981) Multiple attribute decision making: Methods and applications. New York: Springer-Verlag.

Jahanshahloo, G. R., Lotfi, F. H. and Izadikhah, M. (2006) An algorithmic method to extend TOPSIS for decision-making problems with interval data, Applied Mathematics and Computation, 175(2), pp. 13751384. http://dx.doi.org/10.1016/j.amc.2005.08.048

Kalibatas, D., Zavadskas, E. K. and Kalibatienè, D. (2012) A method of multi-attribute assessment using ideal alternative: Choosing an apartment with optimal indoor environment, International Journal of Strategic Property Management, 16(3), pp. 338-353. http:// dx.doi.org/10.3846/1648715X.2012.722567

Karlin, S. and Studden, W. J. (1966) Tchebycheff systems: with applications in analysis and statistics. New York: Interscience Publishers.

Konstantinou, T. and Knaack, U. (2011) Refurbishment of residential buildings: A design approach to energy-efficiency upgrades, Procedia Engineering, 21, pp. 666675. http://dx.doi.org/10.1016/j.proeng.2011.11.2063

Maity, S. R., Chatterjee, P. and Chakraborty, S. (2012) Cutting tool material selection using grey complex proportional assessment method, Materials \& Design, 36, pp. 372-378. http://dx.doi.org/10.1016/j.matdes.2011.11.044

Mickaityte, A., Zavadskas, E. K., Kaklauskas, A. and Tupenaite, L. (2008) The concept model of sustainable buildings refurbishment, International Journal of Strategic Property Management, 12(1), pp. 53-68. http://dx.doi.org/10.3846/1648-715X.2008.12.53-68

Moore, R. E. (1966) Interval analysis. New Jersey: Prentice-Hall.

Opricovic, S. and Tzeng, G. H. (2004) Compromise solution by MCDM methods: A comparative analysis of VIKOR and TOPSIS, European Journal of Operational Research, 156(2), pp. 445-455. http://dx.doi. org/10.1016/S0377-2217(03)00020-1

Rezaeiniya, N., Zolfani, S. H. and Zavadskas, E. K. (2012) Greenhouse locating based on ANP-COPRAS-G methods - an empirical study based on Iran, International Journal of Strategic Property Management, 16(2), pp.188-200. http://dx.doi.org/10.3846/164871 5X.2012.686459

Roy, B. (1968) Classement et choix en présence de points de vue multiples (la méthode ELECTRE), Revue française d'automatique, d'informatique et de recherche opérationnelle. Recherche opérationnelle, 2(8), pp. $57-75$.
Saaty, T. L. (1990) An exposition of the AHP in reply to the paper "Remarks on the analytic hierarchy process", Management Science, 36(3), pp. 259-268. http://dx.doi.org/10.1287/mnsc.36.3.259

Short, C. A., Cook, M., Cropper, P. C. and Al-Maiyah, S. (2010) Low energy refurbishment strategies for health buildings, Journal of Building Performance Simulation, 3(3), pp. 197-216. http://dx.doi. org/10.1080/19401490903318218

Stanujkic, D., Magdalinovic, N., Jovanovic, R. and Stojanovic, S. (2012) An objective multi-criteria approach to optimization using MOORA method and interval grey numbers, Technological and Economic Development of Economy, 18(2), pp. 331-363. http:// dx.doi.org/10.3846/20294913.2012.676996

Stanujkic, D., Magdalinovic, N., Stojanovic, S. and Jovanovic, R. (2011) Extension of ratio system of MOORA method for solving decision-making problems with interval data, Informatica, 23(1), pp. $141-154$.

STR 1.12.06 (2002) Building the intended use and lifetime. Ministry of Environment of the Republic of Lithuania.

STR 2.01.09 (2005) Energy efficiency of buildings. Energy performance sertification. Ministry of Environment of the Republic of Lithuania.

STR 2.05.01 (2005) Building partition thermal technique. Ministry of Environment of the Republic of Lithuania.

Venckus, N., Bliūdžius, R., Poderytè, J. and Burlingis, A. (2012) The heating load determination of low energy buildings in northern climate, Journal of Civil Engineering and Management, 18(6), pp. 828-833. http:// dx.doi.org/10.3846/13923730.2012.720938

Zavadskas, E. K., Kaklauskas, A., Turskis, Z. and Tamošaitienè, J. (2008) Selection of the effective dwelling house walls by applying attributes values determined at intervals, Journal of Civil Engineering and Management, 14(2), pp. 85-93. http://dx.doi. org/10.3846/1392-3730.2008.14.3

Zavadskas, E. K., Kaklauskas, A., Turskis, Z., Kalibatas, D. (2009a) An approach to multi-attribute assessment of indoor environment before and after refurbishment of dwellings, Journal of Environmental Engineering and Landscape Management, 17(1), pp. 5-11. http:// dx.doi.org/10.3846/1648-6897.2009.17.5-11

Zavadskas, E. K., Kaklauskas, A., Turskis, Z. and Tamošaitienè, J. (2009b) Multi-attribute decisionmaking model by applying grey numbers, Informatica, 20(2), pp. 305-320. 